\title{
FIRST RECORD OF MOTHOCYA ARROSOR BRUCE, 1986 PARASITIZING EULEPTORHAMPHUS VIRIDIS (VAN HASSELT, 1823) FROM INDIA
}

\author{
P. Vigneshwaran ${ }^{\mathrm{a} *}$ and S. Ravichandran ${ }^{\mathrm{a}, \mathrm{b}}$ \\ ${ }^{a}$ Centre of Advanced Study in Marine Biology, Annamalai University, Parangipettai - 608 502, India \\ ${ }^{\mathrm{b}}$ Government Thirumagal Mills College, Gudiyatham - 632 602, Tamil Nadu, India \\ *Corresponding author. Email: vigneshwaran0613@gmail.com
}

\author{
Article history \\ 14 September 2020; \\ accepted 15 February 2021
}

Keywords:

cymothoid; Mothocya; fish

parasites; first report; India

\begin{abstract}
The first record of Mothocya arrosor Bruce, 1986 parasitizing ribbon halfbeak fish Euleptorhamphus viridis is here reported from the southeast coast of India. The important characters distinguishing $M$. arrosor from other species in the genus include the body slightly twisted to one side, dorsum weakly convex, coxae of pereonites 6 and 7 distinctly rounded, pleon more completely overlapped by pereonite 7, pleonite 1 scarcely visible in dorsal view, uropod peduncle longer than rami, lacking strongly convex medial and lateral margins. The damage of gill rakers and erosion of gill lamellae were the acute gross lesions observed as a result of isopod infestation.
\end{abstract}

Cymothoids are one of the most recognisable groups of isopods and represent obligate ectoparasites of various marine, brackish and freshwater fish species (Smit et al. 2014). These large ( $>6 \mathrm{~mm}$ ) aquatic parasites are commonly found attached to the host surface (exterior body), inside the buccal cavity, or inside the branchial cavity of the host. This position of attachment is usually genus- or species-specific (Smit et al. 2014; Ravichandran et al. 2019) and host specificity can range from highly specific to general (Ghani 2003; Smit et al. 2014). Branchial cavity inhabiting cymothoids are typically found in pairs, consisting of a female and a male, attached to opposite gill cavities of a host (Aneesh et al. 2016a). These cymothoids mainly feed on the gill filaments, possibly causing blood loss, decrease in respiratory efficiency, and reduction in growth rate (Lester 2005; Östlund-Nilsson et al. 2005).

Mothocya Costa, in Hope, 1851 is one of the most wellknown gill-attaching cymothoid genera parasitizing marine fishes. Bruce (1986) and Hadfield et al. (2014, 2015) revised and redefined this genus and currently, 31 valid species are recognized (Boyko et al. 2008). Until the record described in this paper, five species of the genus had been reported from Indian waters, namely, Mothocya plagulophora (Haller, 1880) (Bruce 1986; Ravichandran et al. 2011], Mothocya renardi (Bleeker, 1857) (Bruce 1986; Aneesh et al. 2016b), Mothocya karobran Bruce 1986 (Rameshkumar et al. 2014a), Mothocya collettei Bruce 1986 (Aneesh et al. 2016a) and Mothocya melanosticta (Schiöedte \& Meinert, 1884) (Vigneshwaran et al. 2019).

Recently, on 13 March 2020, a cymothoid isopod iden- tifiable as Mothocya arrosor Bruce, 1986 was collected in Parangipettai, Tamilnadu, south-eastern coast of India $\left(11^{\circ} 29^{\prime} \mathrm{N} 70^{\circ} 64^{\prime} \mathrm{E}\right)$. This collection constitutes the first Indian record of $M$. arrosor from the host fish ribbon halfbeak Euleptorhamphus viridis (van Hasselt, 1823) (Beloniformes: Hemiramphidae) and the sixth species of this isopod genus known from the country. Out of 46 E. viridis examined, 32 specimens were parasitized by $M$. arrosor. A total of 37 (28 female and 9 male) M. arrosor were collected. Voucher specimens were deposited in the Marine Biology Reference Museum, Centre of Advanced Study in Marine Biology, Annamalai University, Parangipettai, India (CAS/MBRM C-701 to C-710).

Mothocya arrosor can be distinguished by the body slightly twisted to one side, dorsum weakly convex, widest at pereonite 5, rostrum weakly produced (Figures 1a, b, c; 2a, b); coxae of pereonites 6 and 7 distinctly rounded (Figures 1a, b, c; 2a, b); pleon more completely overlapped by pereonite 7 (Figure 2a, b); pleonite 1 scarcely visible in dorsal view; pleotelson longer, forming a complete semicircle; uropod peduncle longer than rami, lacking strongly convex medial and lateral margins, while the endopod is more acutely narrowed (Figure $2 \mathrm{~g}$ ). The brood pouch is made up of seven pairs of overlapping oostegites arising from bases of pereopods 2 to 6 (Figure 2f). The morphological characters of the Indian specimens of $M$. arrosor agree with those mentioned by Bruce (1986). The morphological variations are observed between the Indian specimen and holotype specimen (USNM 216337, see in Bruce (1986)), the body is generally evenly ovoid in the present specimen, but in the holotype specimen 


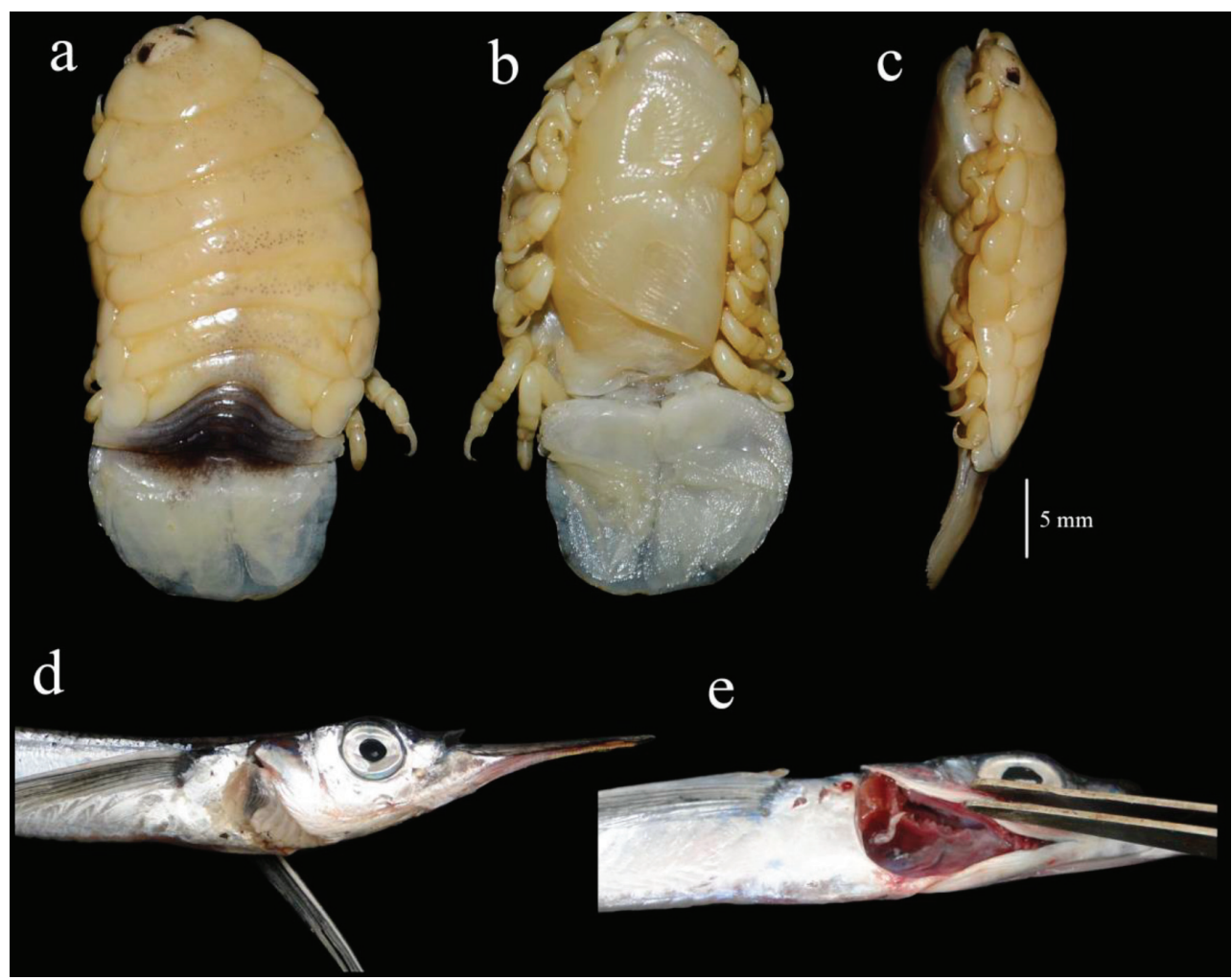

Figure 1. Mothocya arrosor Bruce, 1986 ovigerous female (27.6 mm) (CAS/MBRM C-701): a, dorsal view; b, ventral view; c, lateral view; d, M. arrosor attached in the gill filaments of Euleptorhamphus viridis; e, large pitted scar formed in the branchial cavity of the host due to M. arrosor.

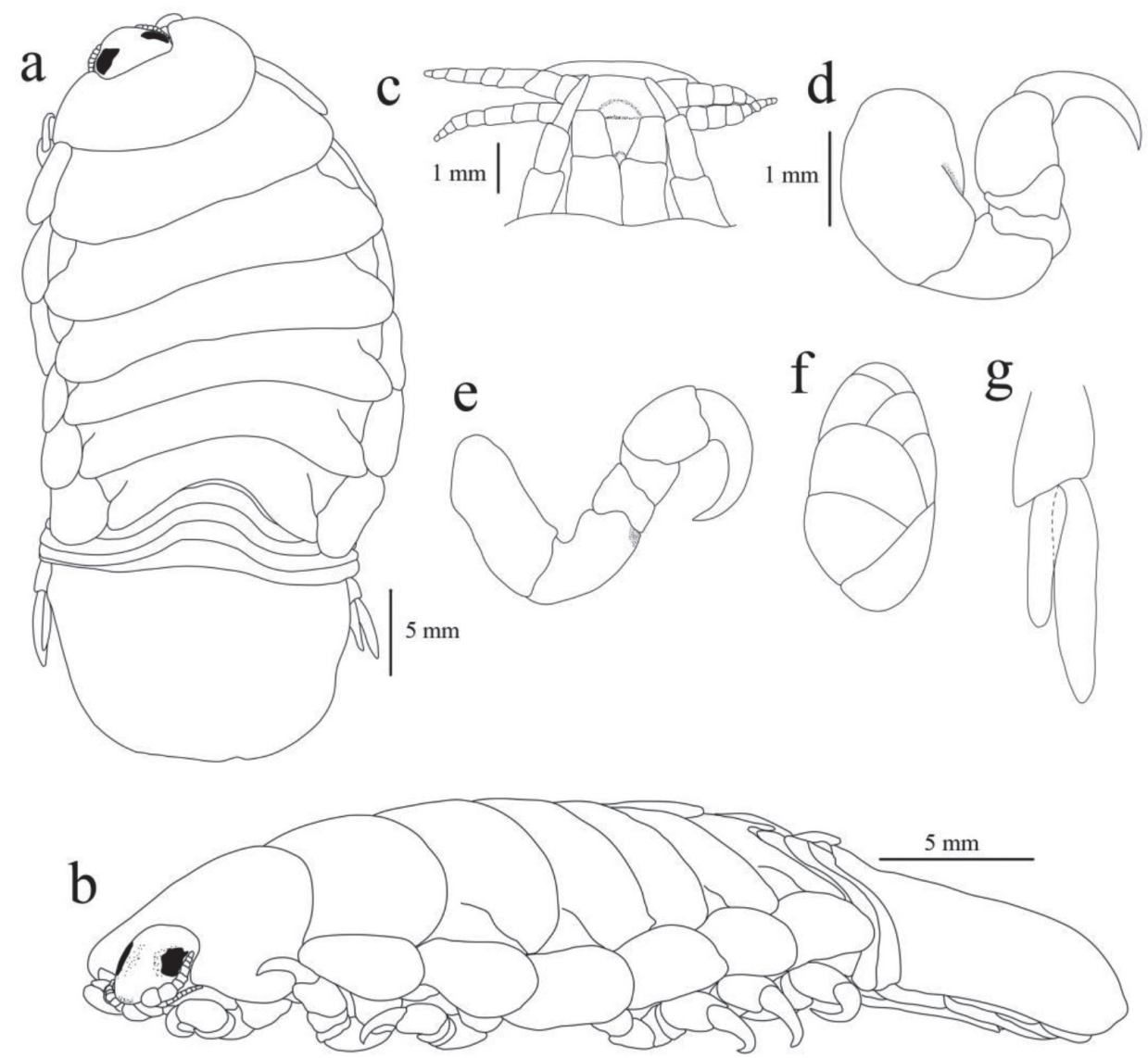

Figure 2. Mothocya arrosor Bruce, 1986 ovigerous female (27.6 mm) (CAS/MBRM C-701): a, dorsal view; b, dorso-lateral view; c, mouthpart with antennula and antenna; d, pereopod 1; e, pereopod 7; f, brood pouch; g, uropod. 
it is less distinctly pyriform. In most specimens, the lateral margins of pereonite 7 overlap pleonites, 1 to 3 . In immature females, fewer pleonites are overlapped. Mothocya arrosor is similar to M. melanosticta, from which it differs principally in having a larger broader pleotelson and more acute uropods. Maxilliped article 3 has four recurved spines, and mandible palp article 3 is more slender. Pereopods are similar to those in M. melanosticta, but dactyls are more slender; pereopod 7 is much larger than pereopod 1 , with coarse pitting on ischium, merus, and carpus (Figure 2d, e).

Mothocya is found in all oceans and is primarily tropical and subtropical in its distribution (Ravichandran et al. 2019). Bruce (1986) stated that M. arrosor is known to occur in tropical oceans: Kenya, Phoenix Islands in the West Pacific, North Borneo, Clipperton and Galapagos Islands in the East Pacific and also in subtropical waters: New South Wales in Australia and Gulf of California in the East Pacific. The current material was collected from the south-eastern coast of India, which is situated in the tropics. This Indian Mothocya is commonly found parasitizing the gill chambers of the host from the family Hemiramphidae and Belonidae. So far, M. arrosor has only been recorded from the host fish Euleptorhamphus viridis (Bruce 1986; Present study), a wide-ranging pelagic species (Collette 1974).

Mothocya arrosor occurs in the branchial chamber of the host fish and its position is highly specific. Mothocya arrosor attaches itself to the dorsal part of the host E. viridis' branchial cavity, with the cephalon to the posterior end of the host and with its ventral side (brood pouch/abdomen) directed inwards, facing the gill filaments (Figure 1d). Generally, Mothocya parasites were found in the middle of the second and third gill chambers of host fishes. Mothocya species have an asymmetrical body, twisted to the right when inhabiting the left gill chambers and twisted to the left when occupying the right gill chambers. Likewise, Rameshkumar et al. (2014a) and Vigneshwaran et al. (2019) reported such mode of attachment in M. karobran from spottail needlefish Strongylura strongylura and in M. melanosticta from blue flyingfish Exocoetus volitans. Commonly, male and ovigerous female pairs were found occupying the same branchial cavity. Similarly, Rameshkumar et al. (2014b) and Aneesh et al. (2016b) found that similar site of attachment for other species within the group of Mothocya and their host fishes. A large pitted scar formed in the branchial cavity of the host due to the overall size and shape of the parasite $M$. arrosor. In cases of larger parasites, the observed damage in the branchial cavity of the fishes was greater. The parasitic cymothoids cause an acute harmful effect on their host fishes. Our findings stated that the gill arches of the infected fish revealed a significant effect on their host, including acute basihyal damage which was more distinct in the gill chamber where the female parasite was sheltered. In the same way, Vigneshwaran et al. (2019) documented that M. karobran, M. renardi and $M$. melanosticta had a severe effect on the branchial chamber of the infected fishes.

The present observation of M. arrosor is a new record for Indian fauna. The atrophied gill filaments and branchial pits observed in the infested gill cavity are apparently due to the permanent occupancy of the parasite. This aspect of host parasitic interaction demands a further study at physiological and histopathological levels to quantitatively evaluate the deleterious effects of these branchial cymothoids on their host fishes. Infestation affects the normal growth of the host fish and also probably leads to high levels of secondary infections.

\section{ACKNOWLEDGEMENT}

Authors are thankful to Dr Kerry Hadfield and Dr Melissa B. Martin for their help on confirmation of specimens. We are also thankful to the authorities of Annamalai University, Tamil Nadu for the facilities, support and encouragements.

\section{CONFLICT OF INTEREST}

The authors declare that they have no conflict of interest.

Author's contribution: PV is the main worker on the topic and prepared the draft of the manuscript with identification, drawings and interpretation of the results. SRC drew out the concept, supervised the manuscript and critically reviewed for improving the quality of the manuscript. Both the authors read and approved the final manuscript.

\section{REFERENCES}

Aneesh, P. T., A. K. Helna, and K. Sudha. 2016a. Branchial cymothoids infesting the marine food fishes of Malabar Coast. Journal of Parasitic Diseases 40 (4): 1270-1277.

Aneesh, P. T., K. Sudha, A. K. Helna, and G. Anilkumar. 2016b. Mothocya renardi (Bleeker, 1857) (Crustacea: Isopoda: Cymothoidae) parasitizing Strongylura leiura (Bleeker) (Belonidae) off the Malabar coast of India: Redescription, occurrence and life-cycle. Systematic parasitology 93: 583-599. https://doi.org/10.1007/ s11230-016-9646-8

Boyko, C. B., N. L. Bruce, K. A. Hadfield, K. L. Mer- 
rin, Y. Ota, G. C. B. Poore, S. Taiti, M. Schotte, and G. D. F. Wilson (eds) 2008 (onwards). World Marine, Freshwater and Terrestrial Isopod Crustaceans database. Cymothoidae Leach, 1818. Accessed through: World Register of Marine Species at: http://www. marinespecies.org/aphia.php? $\mathrm{p}=$ taxdetails\&id $=118416$ on 2020-04-23

Bruce, N. L. 1986. Revision of the isopod crustacean genus Mothocya Costa, in hope, 1851 (Cymothoidae: Flabellifera), parasitic on marine fishes. Journal of natural history 20: 1089-1192.

Collette, B. B. 1974. The garfishes (Hemiramphidae) of Australia and New Zealand. Record of Australian Museum 29: 11-105.

Ghani, N. 2003. Isopod parasites of marine fishes of Pakistan. Proceedings of Pakistan Congress of Zoology 23: 217-221.

Hadfield, K. A., P. C. Sikkel, and N. J. Smit. 2014. New records of fish parasitic isopods of the gill-attaching genus Mothocya Costa (in hope) 1851 from the Virgin Islands, Caribbean, with the description of a new species. Zookeys 439: 109-125.

Hadfield, K. A., N. L. Bruce, and N. J. Smit. 2015. Review of Mothocya Costa, in hope, 1851 (Crustacea: Isopoda: Cymothoidae) from southern Africa, with the description of a new species. African Zoology 50 (2): 147-163.

Lester, R. J. G. 2005. Crustacean parasites. In Marine Parasitology, edited by Rohde K., 592. Melbourne, Australia: CSIRO Publishing.

Östlund-Nilsson, S., L. Curtis, G. E. Nilsson, and A. S. Grutter. 2005. Parasitic isopod Anilocra apogonae, a drag for the cardinal fish Cheilodipterus quinquelineatus. Marine Ecology Progress Series 287: 209-216.

Rameshkumar, G., S. Ravichandran, and K. Sivasubramanian. 2014a. A new record of parasitic isopod for the Indian fauna (Mothocya karobran Bruce, 1986) from Strongylura strongylura in the Pazhayar region, southeast coast of India. Journal of parasitic diseases 38 (3): 328-330. https://doi.org/ 10.1007/s12639-013-0268-7

Rameshkumar, G., M. Ramesh, S. Ravichandran, J. P. Trilles, and S. Subbiah. 2014b. Host-parasite relationships Mothocya plagulophora parasitizing Hemiramphus far in the southeast coast of India. Journal of parasitic diseases 39 (4): 645-648. https://doi.org/10.1007/ s12639-014-0438-2

Ravichandran, S., G. Rameshkumar, and J. P. Trilles. 2011. New records of two parasitic cymothoids from Indian fishes. Journal of parasitic diseases 35 (2): 232-234. https://doi.org/10.1007/s12639-011-0046-3

Ravichandran, S., P. Vigneshwaran, and G. Rameshkumar. 2019. A taxonomic review of the fish parasitic isopod family Cymothoidae Leach, 1818 (Crustacea: Isopoda: Cymothooidea) of India. Zootaxa 4622 (1): 1-99.

Smit, N. J., N. L. Bruce, and K. A. Hadfield. 2014. Global diversity of fish parasitic isopod crustaceans of the family Cymothoidae. International Journal for Parasitology Wildlife 3: 188-197.

Vigneshwaran, P., S. Ravichandran, Melissa B. Martin, and D. Krthick Rajan. 2019. First record of parasitic isopod Mothocya melanosticta (Schiödte and Meinert, 1884) (Isopoda: Cymothoidae) on blue flying fish Exocoetus volitans and Indian sardine Sardinella sindensis from the southeast coast of India. Thalassas 35 (1): 99-107. 